\title{
RUTH DONNER*
}

\section{Dual Nationality in International Law}

\begin{abstract}
The presentation begins with introductory remarks centred principally on the topicality of the legal status of dual nationals. Whereas earlier the doctrine of State sovereignty required that an individual have only one nationality, the status of dual nationality is now increasingly accepted, though not created, by States. The development of human rights law is of importance insofar as statelessness is now considered to be a greater evil. It then continues with some basic principles in international law, the first being that it is for each State to decide who are its nationals. This leads to a discussion of some landmarks in the development of the international law of nationality: the Tunis and Morocco Nationality Decrees before the PCIJ in 1923; the League of Nations codifying Convention on Certain Questions Relating to the Conflict of nationality Laws, 1930; and the Nottebohm case before the ICJ, 1953, in particular. Te greatest contribution to the topic has come from the Iran-United States Claims Tribunal, for three reasons: for rejecting Article 4 of the 1930 Convention, embodying the principle of non-responsibility; further, it clarified how dominant and effective nationality can be determined for the purposes of the nationality of claims; and it developed the equitable doctrine contained in the caveat to Case A/18 that the status of dual nationality must not be used unjustly or fraudulently. Lastly, the possibility of a "dormant" nationality is accepted, and the European Convention on Nationality, 1997, and the International Law Commission's drafts on Diplomatic Protection noted.
\end{abstract}

Keywords: public international law, dual national status, dominant and effective nationality, diplomatic protection, Iran-United States Claims Tribunal, dormant nationality

\section{Introductory Remarks}

The subject of my presentation ${ }^{1}$ is both an interesting and a topical one. I say 'interesting' because, though not unique in this, questions relating to dual nationality arise in national law, private international law-or, as the Americans say, conflict of laws-and public international law. Public international law comes last, but in this questions of nationality touch on the very definition of

* Former Adjunct Professor in Public International Law, Faculty of Law, University of Helsinki.

E-mail: joakim.donner@kolumbus.fi

1 This is the written version of a talk given at a Symposium on "Dual Citizenship as a Legal Problem" held at the Hungarian Academy of Sciences, Budapest, on Monday, 3 October 2005. 
statehood, the existence of a permanent population being an essential precondition for it.

And I say 'topical' because whereas when national status was the sole link between the individual and international law, and allegiance and protection the links between the individual and the ruler, it was for each individual to have one, and only one, nationality. At the Hague Conference on the Codification of International Law, 1930, there was reference to the 'twin evils' of statelessness and dual nationality in connection with the Convention on the Conflict of Nationality Laws. In his classic work on Dual Nationality of 1961, Professor Bar-Yaacov refers to the 'problems' of dual nationality.

In recent years, however, it has become more common for countries to recognize the status of dual nationality. This is not to say that States create dual nationals. On the contrary, it only means that States recognize that their nationals may also possess the nationality of another State and that they do not lose their nationality by operation of law on acquiring another one, as, for example, was common practice when a woman acquired the nationality of her husband on marriage. One can mention the recent nationality legislation of Spain (2002), Finland (2003) and Ireland (2002). As a matter of policy, the Egyptian Minister of the Interior was using his administrative powers in 2004 to pass Egyptian nationality to children of Egyptian mothers and alien fathers, mostly from neighbouring Arab states, pending amended legislation permitting married women to retain their nationality. Since 1998, Mexicans naturalized in the United States have been able to retain Mexican nationality.

Acceptance of dual national status in national law has resulted in renewed interest in dual nationality as a sociological fact and as a problem in political science. Thus the 1997 publication of the British Institute of International and Comparative Law entitled, Citizenship. The White Paper lists in Part One eighteen "Hallmarks of Citizenship", of which 14 are rights and 4 duties.

Also of present concern is the question of how far modern developments in human rights law are relevant to our topic.

Art. 15 of the UN General Assembly's 1948 Universal Declaration of Human Rights states that "Everyone has the right to a nationality." Art. 24 (3) of the UN Covenant on Civil and Political Rights, 1966, and Art. 7 (9) of the UN Convention on the Rights of the Child, 1989, provide for a child's right to citizenship, or nationality. In the International Convention on the Elimination of Racial Discrimination, 1966, Art. 5 (d) (iii) refers to "The right to nationality." However, these articles do not amount to a right to a specific nationality, and highlight the dysfunctional, or asymmetrical, nature of international human rights law. A State, by virtue of its sovereign powers, may divest itself of rights in favour of individuals, but it cannot in the same manner pass over its 
duties and liability for civil wrongs. International criminal courts are another matter. A State cannot be sentenced to prison.

On the other hand, Art. 15 of the 1948 Universal Declaration continues, "No one shall be arbitrarily deprived of his nationality." Other attempts have been made to curb the number of stateless persons. The UN Convention on the Reduction of Statelessness, 1961, which entered into force in 1975, went further than earlier enactments in that it placed an obligation on States. Deprivation of nationality is not just condemned when "arbitrary", but when it results in statelessness (Art. 8). States parties undertake to grant nationality to persons, otherwise stateless, who reside on its territory.

In November 1999 the Organization for Security and Cooperation in Europe adopted the Charter for European Security at Istanbul. There it was stated that "no one should be deprived of his or her nationality arbitrarily... We also commit ourselves to further the international protection of stateless persons." With the development of human rights law it has become clear that statelessness is a greater "evil" than dual nationality.

\section{Dual Nationality and International Law}

\section{Some basic principles}

The basic principles in public international law as regards this topic-bearing in mind that nationality differs from citizenship, which is more relevant in national law, and also from "ethnic nationality"-may be listed as follows:

(a) It is for each State to determine who are its nationals, and if this should lead to a person possessing two nationalities it does not mean half of one nationality and half of another. ${ }^{2}$

(b) A State cannot decide who are the nationals of another State. For example, an English court has stated that there is no such thing as a German national by English law. ${ }^{3}$

And to this one may add:

(c) There is no such thing as a State's national by virtue of international law.

I could mention two instances when an international body has been confronted with this, though both are concerned with reinstatement of an earlier existing nationality.

${ }^{2}$ Donner, R.: The Regulation of Nationality in International Law. 2nd ed., New York, 1995. 205.

${ }^{3}$ Oppenheimer v. Cattermole; Weekly Law Reports (1975), 347. 
First, the case of Mr Baruch Ivcher Bronstein, a national of Israel by birth, who acquired Peruvian nationality by naturalization in 1984 and was deprived of it in 1997 following his broadcasts disseminating news on torture committed by members of the Peruvian Army Intelligence Service. On March 31, 1999, the Inter-American Commission on Human Rights submitted the case to the InterAmerican Court of Human Rights and requested that the Court order Peru to restore and ensure Mr Bronstein's full enjoyment of his rights that had been violated, and in particular that he be able to have his Peruvian nationality fully and unconditionally recognized. ${ }^{4}$

In the Eritrea-Ethiopia Claims Commission, Eritrea requested, inter alia, that the Commission order the reinstatement of the Ethiopian nationality of tens of thousands of people, referring to Ethiopian nationals of Eritrean "descent, blood or affiliation" who were deprived of their Ethiopian nationality during the conflict of 1998-2000. The Commission found this to be outside its jurisdiction. ${ }^{5}$ Further to this, the Commission recognized that some States permit their nationals to possess another nationality while others do not: "International law prohibits neither position". 6

\section{Some landmarks in public international law}

The Advisory Opinion of the Permanent Court of International Justice in the Tunis and Morocco Nationality Decrees ${ }^{7}$ was the first pronouncement of the International Court regarding nationality questions. There Britain had objected to French decrees of 1921 granting French nationality also to British nationals resident in the French protectorates of Tunisia and the French zone of Morocco, without giving such persons an option of nationality, and had finally taken the matter to the Council of the League. France, on the other hand, argued that nationality questions were solely within the domestic jurisdiction of States, and hence outside the competence of the League and the Permanent Court. The question of competence was put before the Court by the League, and in its Opinion the Court stated, in a famous passage: "The question whether a certain matter is or is not solely within the jurisdiction of a State is an essentially relative question; it depends upon the development of international relations.

4 International Legal Materials, 125 (2001), 40.

5 Partial Award, Civilians Claims, Eritrea's Claims 15, 16, 23 \& 27-32, December 17, 2004, Paragraphs 23-25.

6 Ibid. paragraph 59.

7 Permanent Court of International Justice, Series B, No. 4 (1923) 24. 
Thus, in the present state of international law questions of nationality are, in the opinion of the Court, in principle within the reserved domain."

This left open the development of international law as regards nationality. In the League of Nations codification of international law, the Committee of Experts set up by the League in 1924 considered a number of topics as possibly ripe for codification, finally settling on three topics for the Codification Conference, one of which was Nationality. The resulting Hague Convention on Certain Questions Relating to the Conflict of Nationality Laws, 1930, entered into force in 1937 and was, as already mentioned, especially concerned with cases of dual nationality. In particular, Art. 4 stated: "A State may not afford diplomatic protection to one of its nationals against a State whose nationality such person also possesses." "This was so drafted in order to ensure the principle of non-responsibility, that a State was not responsible in the international sphere for injurious acts against its own subjects.

On the other hand, dual national status in fact was implicitly recognized in the Convention. Where a conflict arose, account should be taken of the person's choice. Thus, Art. 5 of the Convention: "Within a third State a person having more than one nationality shall be treated as if he had only one... [A] third State shall recognize exclusively in its territory either the nationality of the country in which he is habitually and principally resident, or the nationality of the country with which in the circumstances he appears to be in fact most closely connected."

Similar wording appears in Art. 1 of the Protocol Relating to Military Obligations in Certain Cases of Double Nationality. ${ }^{9}$ A dual national is liable for military service in that country of his nationality where he ordinarily or habitually resides. This is a formula applied in treaty law concerning military service of dual nationals. So, too, in other connections as, for example, for judges on international courts or, indeed, international civil servants in general. This was applied most recently for judges on the ICTY or the ICTR (the International Criminal Tribunals for the Former Yugoslavia and Rwanda respectively) who might be nationals of two or more States. Security Council Resolution 1411 of 17 May 2002 amended Art. 12 of the ICTY statute and Art. 11 of the ICTR statute, providing that such judges be regarded as bearing solely the nationality of the State in which they "ordinarily exercise civil and political rights." The wording is slightly different.

8 League Nations Treaty Series, Vol. 179, 9. The Preamble stated that every person should have "one nationality only." Donner: op. cit. 46, note 47.

9 League Nations Treaty Series, Vol. 178. 227. 
The Nottebohm case before the present International Court of Justice further clarified the meaning of a dual national's "close connection" with the State of one of his nationalities. The principal facts of this case were as follows: Friedrich Nottebohm was born in Hamburg, Germany, in 1881 and under German law was a German national. In 1905 he moved to Guatemala and resided and worked there until his arrest in 1943. In 1939, shortly before the outbreak of the Second World War, Nottebohm went to Liechtenstein and there acquired Liechtenstein nationality within a matter of weeks, before returning to Guatemala. This was in accordance with the Liechtenstein Law of Nationality of 1934, which permitted dispensation from the normal residence requirements in special circumstances. He then lost German nationality. After the end of the War Liechtenstein, as the country of his nationality, espoused Nottebohm's claim and resorted to international judicial proceedings, before the International Court of Justice, claiming special and general damages for Guatemala's wrongful arrest, detention, and expulsion of Mr Nottebohm (as well as) the restitution of property wrongfully seized from him between 1942 and 1946. Here Liechtenstein exercised its right to diplomatic protection of one of its nationals.

In its 1953 Judgment the Court dismissed Guatemala's preliminary objection to jurisdiction on the grounds that the Court was not properly seised of the case. ${ }^{10}$ In its 1955 Judgment, ${ }^{11}$ on the merits, the Court dismissed Liechtenstein's claim as inadmissible on the grounds that the factual connection between Nottebohm and Liechtenstein "in the period preceding, contemporaneous with, and following his naturalization" was found not to be sufficiently close. ${ }^{12}$ Before that, the Court had stated that "nationality is a legal bond having as its basis a social fact of attachment, a genuine connection of existence..." ${ }^{13}$ But the Court here was dealing not so much with the requirement of a genuine link for purposes of naturalization but with a question of opposability. This is clear in that the Court goes on to state that Liechtenstein was "not entitled to extend its protection to Nottebohm vis-à-vis Guatemala."14 The Court did not overrule Liechtenstein's conferment of nationality on Nottebohm. It could not do that. Nor did it revive his German nationality. Here I do not entirely agree with the

${ }^{10}$ I.C.J. Reports, 1953. 111.

${ }^{11}$ I.C.J. Reports, 1955. 4.

${ }^{12}$ Ibid. at 24

${ }^{13}$ Ibid. at 22.

${ }^{14}$ Ibid. at 26. 
Encyclopedia of Public International Law ${ }^{15}$ that the Nottebohm case deals "only with diplomatic protection as a consequence of conferment of nationality by naturalization."

At the same time, we must remember that Nottebohm had never acquired Guatemalan nationality. The Iran-United States Claims Tribunal, on the other hand, deals with claims brought by dual Iranian-United States nationals.

\section{The Iran-United States Claims Tribunal}

This was the first major claims commission to function since those established in connection with the peace settlements at the end of World War II. Thirty-four volumes of the Iran-United States Claims Tribunal Reports have so far been published. Volumes 35 and 36 are already referred to as nearing completion.

The agreement to set up the Tribunal, being the Claims Settlement Declaration of 1981, was negotiated-although not face-to-face-between Iran and the United States in the Algerian capital Algiers. Its mandate was "to decide claims of nationals of the United States against Iran and the claims of nationals of Iran against the United States... [that]... arise out of debts, contracts... expropriations or other measures affecting property rights". ${ }^{16}$ It has been estimated that at the time when the Islamic Revolutionary government was established in Teheran, in February 1979, some 40,000 United States nationals were residing and working in Iran. This was mostly in connection with what the late Shah's widow has recently called "the White Revolution". The Tribunal's function was a form of diplomatic protection in that individual claims of U.S. nationals were pre-empted, and withdrawn from United States courts.

The importance of this Claims Tribunal for our topic may be shown in three ways.

Firstly, in case $A / 18,{ }^{17}$ decided on 6 April 1984, the Full Tribunal was requested in accordance with its jurisdiction to interpret the meaning of United States national in Art. II of the Claims Settlement Declaration for purposes of presentation of a claim. This question arose because Iran objected to claims brought by naturalized American citizens on the ground that they were Iranian nationals by birth and Iran does not in its legislation recognize an individual's right to abandon nationality, except under strict conditions. Iran's argument before the Full Tribunal was based principally on Art. 4 of the Hague Con-

${ }^{15}$ Bernhardt, R. (ed.): Encyclopedia of Public International Law, Amsterdam (et al.), 3, (1992) 501 at 506.

${ }^{16}$ Art. II Claims Settlement Declaration, 19 January 1981.

${ }^{17} 5$ Iran-United States Claims Tribunal Reports (U.S.C.T.R), 251. 
vention of 1930, mentioned above, as being the expression of the classic rule of non-responsibility. The Tribunal dealt at length with Iran's argument and then rejected this line of reasoning on the basis of its analysis of historical practice, that international tribunals had long experience of dealing with claims of dual nationals, the doctrine on the subject, and also on an analysis of Art. 4 of the Hague Convention. The Full Tribunal held that Art. 4 must be "interpreted very cautiously", that not only was it more than 50 years old and much had changed since then, but also it was "found in a treaty to which only twenty States are parties..." To this I may add here that Habermas has noted that in 1998 only four member States of the European Community had ratified the Convention.

Taking into account that Art. 4 of the 1930 Convention no longer expresses an unambiguous rule, an international court must still consider the factual connection, the genuine link, between an individual and his State of nationality that would permit that State to grant diplomatic protection against another State whose nationality that person also possesses. The Iran-U.S. Claims Tribunal provides an abundant jurisprudence dealing with the determination of a dual national claimant's dominant and effective nationality.

Without looking at all aspects of this, I want to refer to one point. In his 1999 Hague lectures on "Conflits de Nationalités" ${ }^{18}$ Michel Verwilghen was critical of my treatment of the Malek case before the Tribunal. ${ }^{19}$ I am not sure that I follow his argument as to what I "insinuated", but I was indeed wrong in questioning the Tribunal's scrutiny of the whole life of the claimant in order to determine the dominant and effective nationality during the relevant (for the espousal of a claim) period from the date of the alleged injury until the date of bringing the claim, that is, the 19 January 1981, the date of the agreement to set up the Tribunal. It is general practice that for a dual national, in the "Art. 4" sense, a factual assessment must be made to determine the dominant and effective nationality during the relevant period, and in this a Tribunal, as the International Court in the Nottebohm case, "will consider all relevant factors, including habitual residence, center of interests, family ties, participation in public life and other evidence of attachment." In Malek the Tribunal then continued to elaborate on this, stating that "the entire life of the Claimant, from birth, and all the factors which, during this span of time, evidence the reality and the sincerity of the choice of national allegiance he claims to have made, are relevant." ${ }^{20}$ The rather curious result is that the entire life of the claimant is

${ }^{18}$ Vol. 277 Recueil des Cours.

${ }^{19} 23$ June 1988, 19 Iran-U.S.C.T.R. 48; Donner: op. cit. 89-104.

${ }^{20}$ Ghaffari in 31 Iran-U.S.C.T.R. 60 at 65. 
relevant to determining dominance during the relevant period. ${ }^{21}$ In this the Tribunal shows a steady jurisprudence, in cases both before and after Malek.

Thirdly, the Iran-U.S. Tribunal has contributed to the development of international law regarding dual nationality in its application of the caveat contained in case $A / 18$. This provided that, "In cases where the Tribunal finds jurisdiction based upon a dominant and effective nationality of the claimant, the other nationality may remain relevant to the merits of the claim", and "It is also often admitted that no international protection is given to a dual national as regards rights acquired by him through the use of his 'other nationality', if such rights are validly reserved to its citizens by the other State." 22 Although the Tribunal has found on numerous occasions that there is no cause for a claim to be barred by the caveat (e.g. Ghaffari) it has also found it to be applicable as, most recently, in Aryeh (M) v. Iran. ${ }^{23}$ In particular, the Tribunal concluded here that "while the caveat in Case A18 is relevant to this case, its application should result not in the barring of the entire claim, but in the applying of a discount to the market value of the property". And, "the Tribunal must rely on its discretion to quantify a discount that is reasonable and equitable taking into account all the circumstances in this case". ${ }^{24}$ This invoking of equity is in line with the early Esphahanian case, ${ }^{25}$ citing the Flegenheimer case, ${ }^{26}$ to the effect that international courts may deny jurisdiction in cases of dual nationality "on equitable grounds in cases of fraudulent use of nationality."

The requirement of bona fides appears also in the United Nations Claims Commission. This is a quasi-judicial body, not an arbitral tribunal for traditional diplomatic protection and espousal of claims, set up under Security Council Resolution 692 of 20 May 1991 to handle the circa 2.6 million claims arising out of the Iraqi invasion and occupation of Kuwait. Although eligibility to bring a claim is not based on nationality it is stipulated that Iraqi nationals may not bring claims. This was further clarified in the Governing Council (of the Commission) Decree of 28 November 1991: "Claims will not be considered on behalf of Iraqi nationals who do not have bona fide nationality of another State." 27

${ }^{21}$ Aldrich, G. H.: The Jurisprudence of the Iran-United States Claims Tribunal, 1996. 59.

${ }^{22} \mathrm{~A} / 18$ at $265-266$ and 274.

${ }^{23} 33$ Iran-U.S.C.T.R, 368.

${ }^{24}$ Ibid. 395, paragraphs 85 and 86.

${ }^{25} 2$ Iran-U.S.C.T.R, 161-162.

${ }^{26}$ U.S. v. Italy, 14 UN Reports of International Arbitration Awards, 327 at 378.

${ }^{27}$ See 31 International Legal Materials (1992) 1009. Donner: op. cit. 386. 


\section{4. "Dormant" nationality}

One matter not referred to so far, but of contemporary relevance, is the question of what I have called "dormant" nationality, where one full nationality exists together with a dormant one.$^{28}$ This phenomenon is not quite the same as dual nationality because there are not two, or more, concurrent nationalities of, in principle though not necessarily in fact, equal weight. But it also has the character of dual nationality in that the dormant nationality may be activated at any time, simply on request and following certain formalities.

An example of this occurred in Germany before reunification. ${ }^{29}$ Art. 16 of the West German Basic Law dealt with nationality of the Federal Republic, while Art. 116 covered those persons who possessed German nationality within the borders of territory of the German State as it existed on 31 December 1937. This was in accordance with Art. 146 of the Basic Law in which the concept of a united Germany was reiterated. In the Teso case before the W. German Federal Constitutional Court, $1987,{ }^{30}$ this same concept of a common German nationality was applied in favour of an East German national even though the 1967 Nationality Law of the Democratic Republic had no equivalent to Art. 116 of the Federal Republic's Basic Law. Thus when the inhabitants of the former East Germany streamed west just before the collapse of that State, West German embassies could take them in, in Hungary and Czechoslovakia.

The same applies in other divided States. Thus in the 2001 Irish Nationality and Citizenship Act, "section 3.6.-(1) Every person born in the island of Ireland is entitled to be an Irish citizen." The case of Korea is more complex due to the magnitude of the problems involved: the number of inhabitants is more evenly divided than in the former two Germanies; the poverty is greater in the one half, here the northern; the common border is even more impenetrable; and the neighbours less accommodating. Yet even there I understand that North Koreans who reach South Korea are given South Korean nationality on preferential terms. Citizenship of the European Union adds further interest to this question.

As international law does not prohibit dual nationality, there can be no such prohibition on a State, by virtue of its inherent sovereign powers, granting its nationality preferentially to whomever it pleases. No conflict of nationalities is involved, because the one only becomes active where there is a genuine link

\footnotetext{
${ }^{28}$ Donner: op. cit. 204-i.e. in preference to "virtual" nationality.

${ }^{29}$ Donner: op. cit. 288-291.

${ }^{30}$ (91) International Law Reports, 213-235.
} 
and where the individual invokes his right to it. The nationality is not imposed on the individual against his will because it is only dormant.

\section{Concluding Remarks}

The European Convention on Nationality, $1997,{ }^{31}$ is relevant for a number of the points discussed here. Although this is a regional treaty it is important because there are now forty-six members of the Council of Europe and, in addition, States not members of the Council may be parties to its treaties.

Art. 4 (b) provides: "Statelessness shall be avoided." There is no such prohibition of dual nationality.

On page 16 of the accompanying Explanatory Report it was acknowledged that the conflict of laws arising from multiple nationality was the "most important area which it has not been possible to include in the Convention... However, a growing number of States are making use of the notion of 'habitual residence', when persons regularly and effectively live in a particular place."

Further, the International Law Commission had by August 2004 produced one Preliminary and five consequent numbered Reports on Diplomatic Protection, partly of relevance for our topic today. Thus Art. 6 of the First Report, of 7 March 2000, states: "Subject to Art. 9, paragraph 4, the State of nationality may exercise diplomatic protection on behalf of an injured national against a State of which the injured person is also a national where the individual's [dominant and effective] nationality is that of the former State." A note states that Art. 9, paragraph 4, will read: "Diplomatic protection may not be exercised by a new state of nationality against a previous State of nationality for injury incurred during the period when the person was a national only of the latter State." It is not clear what this adds to the present rules on continuity of nationality.

Finally, and in conclusion, it may be said that the greatest contribution to this topic in recent years has been made by the Iran-United States Claims Tribunal: it has improved on the tools for dealing with complex factual situations in the determination of dominant nationality, and it has applied equitable principles to control the status of dual nationals. This is to say, in international law an individual who has dual nationality has a right to choice as in the objective determination of his dominant and effective nationality, but, also, he has the duty not to abuse this right, as provided in the caveat in the $A / 18$ case.

${ }^{31}$ European Treaty Series, No. 166. 